\title{
FOOD WASTE INDEX AS AN INDICATOR OF MENU ADEQUACY AND ACCEPTABILITY IN A PORTUGUESE MENTAL HEALTH HOSPITAL
}

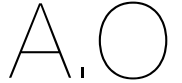

ARTIGO ORIGINAL

1 Faculdade de Ciências da Nutrição e Alimentação da Universidade do Porto, Rua Dr. Roberto Frias, s/n 4200-465 Porto, Portugal

2 Universidade de Trás-os-Montes e Alto Douro, Quinta de Prados, 5000-801 Vila Real, Portugal

${ }^{3}$ Centro de Biotecnologia e Quimica Fina Laboratório Associado,

Escola Superior de Biotecnologia da Universidade Católica Portuguesa,

Edifício de Ciências

Agrárias (FCV2), Rua da Agrária, n. ${ }^{\circ} 747$

4485-646 Vairão, Portugal

${ }^{4}$ GreenUPorto

Sustainable Agrifood

Production Research

Centre,

Edifício de Ciências

Agrárias,

Rua da Agrária, n. 747 ,

4485-646 Vairão, Portuga

5 Instituto Philippe Pinel, Av. Venceslau Brás, 65 Botafogo,

Rio de Janeiro - RJ,

02155-023, Brasil

${ }^{6}$ LAQV-Requimte, Rua Dr. Roberto Frias $s / n$ 4200-465 Porto, Portugal

"Endereço para correspondência:

Ada Rocha

Faculdade de Ciências da Nutrição e Alimentação da Universidade do Porto, Rua Dr. Roberto Frias, $s / n$ 4200-465 Porto, Portug

darocha@fcna.up.pt

Histórico do artigo:

Recebido a 19 de novembro de 2019 Aceite a 21 de janeiro de 2020
ÍNDICE DE DESPERDÍCIO COMO INDICADOR DA ADEQUAÇÃO
DA EMENTA E ACEITABILIDADE NUM HOSPITAL PORTUGUES

Dinangela Oliveira'; Margarida Liz Martins ${ }^{2-4}$; Lucinda Fonseca ${ }^{5}$; Ada Rocha ${ }^{1,4,6}$

\section{ABSTRACT}

INTRODUCTION: Food intake in the hospital environment plays a major role in the nutritional status and, consequently, in the health and well-being of the patient. Hospital malnutrition is highly prevalent in concurrent with a high rate of food waste and nutritional risk. Food waste is related to menu adequacy and meals acceptance in hospitalized patients and should be controlled considering its impacts in health.

OBJECTIVES: To evaluate menu adequacy and acceptability in a long-term mental health hospital.

METHODOLOGY: This observational study was conducted at a Portuguese long-stay mental health hospital. Lunch menus evaluation was performed by the relative frequency of some items based on the AQE-r method (Qualitative evaluation of menus - short version). Meals acceptability was evaluated using food waste index by the weighing method.

RESULTS: Although fruits were offered in the majority of days, the variety was limited. There was a low supply of vegetables and pulses and total absence in some days. The main dish was considered "acceptable" by men (average $21.7 \% \pm 29.5 \%$ SD) and "inadequate" by women $(35.3 \pm 31.9 \%)$ based on the food waste index.

Low temperature of carbohydrate source at the time of consumption was related to a higher food waste index of the main dish $(R=$ -0.110; $p=0.045$ ). It was also observed that patients who wasted more soup are more likely to present a higher waste of the main dish $(R=0.169, p=0.002)$.

CONCLUSIONS: Menus evaluated during the study period were not in accordance with the current dietary recommendations, namely regarding supply of vegetables, fruits, sources of carbohydrates, fish and cooking techniques. High values of food waste index were found among women. Carbohydrate source temperature seems to be related to menu acceptability. Food waste seems to be more related to the patient than to the menu since those who waste more soup also waste more of the main dish.

\section{KEYWORDS}

Acceptability, Adequacy, Food waste, Foodservice, Hospital menu, Menu planning

RESUMO

INTRODUÇÃO: A ingestão alimentar em ambiente hospitalar assume um papel relevante no estado nutricional e consequentemente na saúde e bem-estar dos utentes. A malnutrição hospitalar é altamente prevalente e está associada a níveis elevados de desperdício alimentar e maior risco de desnutrição.

O desperdício alimentar relaciona-se com o grau de adequação das ementas e a sua aceitação em indivíduos hospitalizados e deve ser controlada considerando o seu impacto na saúde.

OBJETIVOS: Avaliar a adequação e aceitabilidade da ementa fornecida num hospital psiquiátrico.

METODOLOGIA: Trata-se de um estudo observacional realizado num hospital psiquiátrico. As ementas do almoço foram avaliadas através da avaliação da frequência relativa de alguns itens, com base no método AQE-r (Avaliação Qualitativa de Ementas - versão resumida). A aceitabilidade das refeições foi avaliada utilizando o índice de restos recorrendo ao método de pesagem. RESULTADOS: Apesar da fruta ser oferecida na maioria dos dias, a variedade era limitada. O fornecimento de produtos hortícolas e leguminosas foi baixo, estando ausente nalguns dias. O prato principal foi considerado "aceitável" pelos indivíduos do sexo masculino $(21,7 \pm 29,5 \%)$ e "inadequado" pelos indivíduos do sexo feminino (35,3 $\pm 31,9 \%)$ considerando o índice de restos. Observou-se que a baixa temperatura da componente de hidratos de carbono no momento de consumo estava relacionada com um maior índice de restos do prato principal $(R=-0,110 ; p=0,045)$. Observou-se que os utentes que desperdiçaram mais sopa tendencialmente também desperdiçaram mais do prato principal $(R=0,169 ; p=0,002)$

CONCLUSÕES: As ementas avaliadas durante o período em estudo não cumpriam as recomendações alimentares, nomeadamente em relação ao fornecimento de produtos hortícolas, fruta, componente de hidratos de carbono, peixe e técnicas de confeção. O valor mais elevado de índice de restos foi encontrado nos indivíduos do sexo feminino. A temperatura da fonte de hidratos de carbono relacionou-se com a aceitabilidade da ementa. O desperdício alimentar parece estar mais relacionado com os utentes do que com a ementa, uma vez que quem desperdiça mais sopa, desperdiça mais da restante refeição.

PALAVRAS-CHAVE

Aceitabilidade, Adequação, Desperdício alimentar, Serviço de alimentação, Ementa hospitalar, Planeamento de ementa 


\section{INTRODUCTION}

Adequate food intake is essential for the control and prevention of disease, as well as to help improving patients recovery (1).

Studies show that there is an inverse relationship between nutritional status and length of hospital stay, which results in prolonged rehabilitation, reduced quality of life and increased use of resources and additional costs in health care (1-3).

Several authors argue that malnutrition among long-term health services, in some cases may be a consequence of the disease, but in others it results from inadequate food intake. This is of particular importance in a mental health hospital (4-7).

According to Grunert et al. (8), food intake in the hospital environment plays a major role in the nutritional status and, consequently, in the health and well-being of the patient.

The nutritional adequacy of meals can be assured by establishing that the average food consumption corresponds to the recommendations (9). Evidence has shown that controlling food waste enables accurate assessment of the adequacy and acceptability of meals. Food waste index (FWI) is determined by the relation between the remaining food (i.e. the food returned in the dish) and the quantity of food served. For Teixeira et al. (10), the lower the food waste index the better the acceptability and the likelihood of the users to satisfy their nutritional needs (11), resulting in better clinical results and lower hospital costs (12).

The qualitative menus evaluation method (AQE) (13) allows for the evaluation of the menu and identification of the factors that interfere with menu quality and, consequently, its nutritional and sensorial adequacy, in the parameters and criteria scientifically recommended (14).

Food waste is related to menu adequacy and meals acceptance in hospitalized patients and should be controlled considering its impacts in health.

\section{OBJECTIVES}

This study aims to evaluate the adequacy and acceptability of the menu offered in a long-term mental health hospital.

\section{MATERIALS AND METHODOLOGY}

An observational, cross-sectional, quantitative study was conducted in a long-stay mental health care center located in the northern region of Portugal between October 2016 and February 2017.

Ethical approval of the Hospital Clinical Direction was obtained and the protection and confidentiality of data collected was guaranteed by using numerical codes associated to each patient.

The hospital has contracted its food service to a private company. The menu follows a cycle of 6-weeks, and a rotation system is established. At lunch, each patient is served with soup, a main course and dessert. A centralized production system and hot sequential distribution (Cook-Serve) is used. Meals are served at the table in the dining room belonging to each ward.

A convenience sampling process was used considering that all individuals were institutionalized at hospital. As inclusion criterion, age of users was defined between 18 and 60 years, following a "general diet" and / or "specific diet" (including boiled and grilled dishes), who agreed to participate voluntarily in the study. All patients who were in isolation or following a modified diet were excluded.

Anthropometric measures were assessed in the morning, before breakfast, in the sense of not disturbing the routine of the service and causing the least discomfort to the patient. Commonly accepted procedures within the scientific community were adopted, according to the internationally recognized standard methodology for anthropometric evaluation (15). Measurements were made twice, and repeated in case of differences higher than $1 \mathrm{~cm}$, and arithmetic averages were calculated.

Some criteria and parameters were adapted from the proposal of criteria for qualitative evaluation of Bessa et al. (16), and Veiros et al.(14), in order to validate compliance with current dietary recommendations. To determine meals adequacy the occurrences of non-conformities were compared with the food waste index. Parameters and classification criteria were established and some factors related to menus quality that impair acceptability were integrated.

For the qualitative evaluation of the menus the short form of qualitative menus evaluation method (AQE), i.e. the AQE-r, was used. This focused on the possible parameters of analysis related to the composition of the daily menu offered, subdivided into different groups (general items of the dish, protein component (CP); source of carbohydrates (AC1); vegetable component (AC2); pulse component (AC3); soup; fruit or dessert and the cooking techniques employed (17). Menu acceptability was evaluated during five consecutive days by quantifying food waste in the form of leftovers, based on the individual weighing method.

The acceptability of the menu was analyzed by quantifying food waste, based on the formula proposed by Teixeira, et al. (10) - Food Waste Index $(\%)=$ weight of plate waste $\times 100 /$ weight of the meal served. To classify the food waste index the evaluation criteria and the cut-off points proposed by Williams et al. (18) were used (Table 1).

Statistical analysis of the data was performed using SPSS Statistics, version 25 for Macintosh. The results were presented as mean (\%) \pm standard deviation (SD) (\%) for quantitative variables and relative frequencies for qualitative variables. The Kolmogorov-Smirnov $Z$ test was used to assess the normality of variables. Pearson's correlation test was used to measure the association between pairs of variables. Student t-test was used to compare the means of two independent samples and the One-way ANOVA to compare means of 3 or more independent samples. Confidence level was set at $95 \%$.

\section{RESULTS}

The sample of this study consisted on 66 hospitalized patients, mostly following a "general diet" (63.6\%). A higher prevalence of males (78.8\%) was observed in the target population and the predominant age groups were patients younger than 40 years (25.8\%) and $41-50$ years (27.3\%) (Table 2).

Despite the prevalence of BMI normality, the majority of patients (77.3\%) presented risk factors for grouped cardio metabolic complications, considering the relation between waist circumference and height above $0.5 \mathrm{~cm}$.

The qualitative evaluation of the menu is presented in Table 4.

It was observed that, although fruits were offered on the majority of days, the variety was low. There was a low supply of vegetables and pulses as side dish, and total absence of these items in some days. Egg and fatty fish as the main source of protein were not offered at all in the period under analysis. There was a predominance of cooking techniques using dry heat ( $45.5 \%$ roasts and $36.4 \%$ fried) in fish dishes of the "general diet" (Table 4).

Food waste index (FWI) classification is presented in Table 5. Food waste index (FWI) was classified as inadequate for $32.4 \%$ of meals served of the "general diet" and $39.2 \%$ of meals served of the "specific diet" (> $30 \%$ ) (Table 5). The evaluation of acceptability based on the food waste index criteria revealed that the main dish was considered "acceptable" by $21.7 \pm 29.5 \%$ of men and "inadequate" by the majority of women $(35.3 \pm 31.9 \%)$.

Age and length of stay were not found to be significantly associated with food waste index ( $p>0.05)$ (data not shown). 
Meals acceptability criteria according to the Food Waste Index

\begin{tabular}{lccc} 
CLASSIFICATION OF MEALS ACCEPTABILITY & EXCELLENT & GOOD & ACCEPTABLE \\
Food waste (\%) & 10 to 15 & 15 to 20 & 20 to 30 \\
\hline
\end{tabular}

Adapted from: Williams P. \& Walton K. (2011) (18)

Table 2

Sociodemographic characterization of the sample, $n=66$

\begin{tabular}{|c|c|}
\hline Sex & \\
\hline Men, \% (n) & $78.8(52)$ \\
\hline Women, \% (n) & $22.2(14)$ \\
\hline \multicolumn{2}{|l|}{ Age (years) } \\
\hline Mean \pm SD & $47.9 \pm 8.8$ \\
\hline \multicolumn{2}{|l|}{ Age groups, $\%$ (n) } \\
\hline$\leq 40$ years old & $25.8(17)$ \\
\hline 41 to 50 years old & $27.3(18)$ \\
\hline 51 to 54 years old & $22.7(15)$ \\
\hline$>55$ years old & $24.2(16)$ \\
\hline \multicolumn{2}{|l|}{ Length of stay (years) } \\
\hline Mean \pm SD & $7.7 \pm 5.9$ \\
\hline \multicolumn{2}{|l|}{ Type of diet } \\
\hline General, \% (n) & $63.6(42)$ \\
\hline Specific, \% (n) & $36.4(24)$ \\
\hline
\end{tabular}

SD: Standard Deviation

\section{Table 3}

Anthropometric characterization of the sample, $n=66$

\begin{tabular}{|c|c|}
\hline VARIABLES & \\
\hline \multicolumn{2}{|l|}{ BMI $\left(\mathbf{k g} / \mathbf{m}^{2}\right)$} \\
\hline Mean \pm SD & $26.6 \pm 6.7$ \\
\hline \multicolumn{2}{|l|}{ Nutritional status } \\
\hline Normal weight (\% of patients) $)^{(a)}$ & 45.5 \\
\hline Overweight (\% of patients) $)^{(a)}$ & 30.3 \\
\hline Obesity (\% of patients) $)^{(a)}$ & 24.2 \\
\hline \multicolumn{2}{|l|}{ Waist circunference (cm) } \\
\hline Mean \pm SD & $95.4 \pm 13.5$ \\
\hline \multicolumn{2}{|l|}{ Waist/hip ratio } \\
\hline Mean \pm SD & $0.6 \pm 0.1$ \\
\hline Cardio metabolic risk (\% of patients) (b) & 77.3 \\
\hline
\end{tabular}

BMI: Body Mass Index

SD: Standard deviation

Source: a= Body Mass Index was calculated according to World Health Organization, 2000; National Institute of Health, 2008; $b=$ Cardio metabolic risk was calculated according to Ashwell et al., 2012.

Table 6 presented food waste index according to menu parameters. It was observed that female $(35.3 \pm 31.9)$ patients wasted more than men $(21.7 \pm 29.5)(p=0,001)$. Food Waste Index was higher for specific diet $(29.5 \pm 33.7$ vs $21.8 \pm 28.3)(p=0,001)$ and for non-composed dishes $(31.9 \pm 31.2$ vs $13.5 \pm 25.7)(p<0.001)$.

It was observed that the type of protein source significantly influenced food waste $(p<0.001)$, being higher in fish dishes than in meat dishes $(31.8 \pm 34.3$ vs $7.8 \pm 14.5$, respectively). Low temperature of carbohydrate source at the time of consumption was related to a higher food waste index of the main dish $(R=-0.110 ; p=0.045)$. It was also observed that the patients who wasted more soup are more likely to present a higher waste of the main course $(R=0.169 ; p=0.002)$.

\section{DISCUSSION OF RESULTS}

Menus adequacy and acceptance are essential for food intake and
Table 4

Qualitative evaluation of menus (AQE-r) - occurrences according to menu type

\begin{tabular}{|c|c|c|}
\hline VARIABLES & GENERAL DIET & SPECIFIC DIET \\
\hline \multicolumn{3}{|l|}{ General items (\%) } \\
\hline Compliance of menu & 46.7 & 36.7 \\
\hline Composed dishes & 43.3 & 36.7 \\
\hline Monocromatic dishes & 23.3 & 23.3 \\
\hline Fried items (\%) & & 30.3 \\
\hline Meat & 6.7 & - \\
\hline Fish & 13.3 & - \\
\hline $\begin{array}{l}\text { Cereals and/or tubers fried or } \\
\text { roasted }\end{array}$ & 10.0 & 3.3 \\
\hline Dishes with added offal/sausage & 26.7 & 10.0 \\
\hline Protein source (\%) & & $0.6 \pm 0.1$ \\
\hline Meat & 53.3 & 56.7 \\
\hline Fish & 40.0 & 43.3 \\
\hline Egg & 3.3 & - \\
\hline \multicolumn{3}{|l|}{ AC1 (\%) } \\
\hline Rice & 56.7 & 56.7 \\
\hline Pasta & 13.3 & 16.7 \\
\hline Potato & 30.0 & 26.7 \\
\hline \multicolumn{3}{|l|}{ AC2 (\%) } \\
\hline Cooked & 6.7 & 13.3 \\
\hline Raw (salad) & 16.7 & 20.0 \\
\hline \multicolumn{3}{|l|}{ AC3 (\%) } \\
\hline Fresh grains & - & 3.3 \\
\hline Dried grains & - & - \\
\hline \multicolumn{3}{|l|}{ Soup (\%) } \\
\hline Vegetables & 70.0 & 70.0 \\
\hline Vegetables and pulses & 20.0 & 20.0 \\
\hline Vegetables and sausage & 10.0 & 10.0 \\
\hline \multicolumn{3}{|l|}{ Dessert (\%) } \\
\hline Fruit & 80.0 & 80.0 \\
\hline Sweet & 20.0 & 20.0 \\
\hline
\end{tabular}

AC1: Source of carbohydrates

AC2: Vegetables

AC3: Pulses

consequently low food waste in hospitalized patients. Dupertuis et al. reported that psychiatric patients were at more risk of malnutrition since they were the most dissatisfied with the meals served (19). In opposite Dias Ferreira et al. reported the lowest food waste values at psychiatric wards (20).

According to our results, there are several inadequacies on menus offered. Vegetable component was presented only in $23 \%$ of general diet and in 33\% in specific diet, pointing to non-compliance with the dietary recommendations $(4,16)$.

These data corroborate the evidence from Lam et al. (21) and Rodriguez et al. (7), who found that intake of long-stay patients were not in compliance with the current recommendations for fiber, folate, vegetables, pulses and vitamin $D$.

The menu must be planned and executed with the inclusion of colorful vegetables and pulses, minimizing the inclusion of 
Table 5

Food Waste Index and meals acceptability for main dish, according to the socio demographic data and type of diet

\begin{tabular}{|c|c|c|}
\hline VARIABLES & $\begin{array}{l}\text { GENERAL DIET } \\
N=210\end{array}$ & $\begin{array}{l}\text { SPECIFIC DIET } \\
N=120\end{array}$ \\
\hline \multicolumn{3}{|l|}{ Global Food Waste Index } \\
\hline$(\%$ Mean $\pm \%$ SD) & $21.8 \pm 28.3$ & $29.5 \pm 33.7$ \\
\hline \multicolumn{3}{|c|}{ Global meals acceptability ${ }^{(a)}(\%)$} \\
\hline Excellent & 56.2 & 48.3 \\
\hline Good & 4.3 & 5.8 \\
\hline Acceptable & 7.1 & 6.7 \\
\hline Inadequate & 32.4 & 39.2 \\
\hline \multicolumn{3}{|l|}{ Men Food Waste Index } \\
\hline$\%$ Mean $\pm \%$ SD & $19.9 \pm 27.5$ & $26.7 \pm 34.3$ \\
\hline \multicolumn{3}{|c|}{ Men meals acceptability ${ }^{(a)}(\%)$} \\
\hline Excellent & 60.0 & 52.9 \\
\hline Good & 3.2 & 8.6 \\
\hline Acceptable & 6.8 & 5.7 \\
\hline Inadequate & 30.0 & 32.8 \\
\hline \multicolumn{3}{|l|}{ Women Food Waste Index } \\
\hline$\%$ Mean $\pm \%$ SD & $39.6 \pm 30.5$ & $33.5 \pm 32.5$ \\
\hline \multicolumn{3}{|c|}{ Women meals acceptability ${ }^{(a)}(\%)$} \\
\hline Excellent & 20.0 & 42.0 \\
\hline Good & 15.0 & 2.0 \\
\hline Acceptable & 10.0 & 8.0 \\
\hline Inadequate & 55.0 & 48.0 \\
\hline
\end{tabular}

(a) Classification considering Williams P. \& Walton K. (2011) (18)

monochromatic dishes that were observed in our study. In addition to having a variety of colors that provide a pleasant visual appearance, the more colorful, the greater the variety of nutrients (6). Dishes with vibrant colors arouse the interest of the consumer, since the first contact with food is visual, besides guaranteeing the consumption of diversified nutrients $(6,14)$.

Our results showed a lower food waste index than other authors, namely Dias-Ferreira et al., that found an overall plate waste of 35\% (20) and Williams and Walton that reported a value of $26 \%$ of food waste in different hospitals (18).

Simzari et al. found a mean percent of plate waste for lunch of $37.7 \pm 29.88$ and reported as the main causes for reducing intake and increasing food waste amounts was nausea, dry mouth, and unwillingness (22). In different studies other factors have been mentioned such as more staying in hospital, prepared special diet, lack of nutritional supplements, low quality delivered meals, inadequate taste and absence of choice, type of diagnosed disease, poor food quality, inappropriate portion sizes, inappropriate meal times, interruptions, and unpleasant surroundings $(18,19,23)$.

There was a great variability in the food waste index for soup, main dish and fruit, which could reflect the physical limitations presented by some patients, dietary prescription, appetite variations and the presentation of some components of the menu. Other Portuguese study report that the main dish account with $52 \%$ of food waste and the least wasted item was soup (12\% of food served) (20). It was also verified that protein component presentation significantly influences food waste. This is also in line with other authors and may be explained by chewing and swallowing impairments frequently observed in this kind of patients $(24,25)$.

It was observed that meal inacceptability was higher for specific diet than for general diet. It may be related to patients characteristics since specific diet was normally served to patients with commorbilities that could reduce appetitte and welfare. Additionally, these meals are
Table 6

Descriptive analyses of Food Waste Index according to menu parameters

\begin{tabular}{|c|c|c|}
\hline VARIABLES & $\begin{array}{l}\text { FOOD WASTE INDEX } \\
\text { MEAN } \pm \text { SD }\end{array}$ & p \\
\hline \multicolumn{2}{|l|}{ Sociodemographic data } & \multirow{3}{*}{$0.001^{\star}$} \\
\hline Men & $21.7 \pm 29.5$ & \\
\hline Women & $35.3 \pm 31.9$ & \\
\hline \multicolumn{2}{|l|}{ Compliance of menus } & \multirow{3}{*}{$<0.001^{*}$} \\
\hline Served = planned & $18.5 \pm 29.2$ & \\
\hline Served $\neq$ planned & $30.6 \pm 30.6$ & \\
\hline \multicolumn{2}{|l|}{ Type of diet } & \multirow{3}{*}{$0.001^{*}$} \\
\hline General & $21.8 \pm 28.3$ & \\
\hline Specific & $29.5 \pm 33.7$ & \\
\hline \multicolumn{2}{|l|}{ Classification of menu } & \multirow{3}{*}{$<0.001^{\star}$} \\
\hline Composed $^{1}$ & $13.5 \pm 25.7$ & \\
\hline Not composed ${ }^{2}$ & $31.9 \pm 31.2$ & \\
\hline \multicolumn{2}{|l|}{ Type of protein source } & \multirow{6}{*}{$<0.001^{\star \star}$} \\
\hline Beef & $14.4 \pm 27.7$ & \\
\hline Chicken, duck, rabbit & $24.7 \pm 29.3$ & \\
\hline Pork & $29,0 \pm 25,2$ & \\
\hline Mixed sources & $7.8 \pm 14.5$ & \\
\hline Fish & $31.8 \pm 34.3$ & \\
\hline \multicolumn{2}{|c|}{ Protein source presentation } & \multirow{5}{*}{$0.003^{\star \star}$} \\
\hline Piece & $27.9 \pm 32.8$ & \\
\hline Shreded & $19.1 \pm 29.8$ & \\
\hline Steaks / Fillets & $33.5 \pm 28.2$ & \\
\hline Minced & $13.8 \pm 22.8$ & \\
\hline \multicolumn{2}{|l|}{ Addition of vegetables to: } & \multirow{3}{*}{$<0.001^{*}$} \\
\hline Protein source & $11.1 \pm 22.6$ & \\
\hline $\mathrm{AC} 1$ & $33.0 \pm 33.4$ & \\
\hline \multicolumn{2}{|l|}{ Addition of pulses to: } & \multirow{3}{*}{$0.001^{*}$} \\
\hline $\mathrm{CP}$ & $12.7 \pm 25.4$ & \\
\hline $\mathrm{AC} 1$ & $28.5 \pm 33.5$ & \\
\hline \multicolumn{2}{|l|}{ AC2 } & \multirow{3}{*}{0.500} \\
\hline Cooked & $27.2 \pm 30.5$ & \\
\hline Raw (saladas) & $31.7 \pm 27.5$ & \\
\hline \multicolumn{2}{|l|}{ Dessert } & \multirow{3}{*}{0.200} \\
\hline Fruit & $4.5 \pm 20.4$ & \\
\hline Sweet & $1.0 \pm 7.9$ & \\
\hline \multicolumn{2}{|l|}{ Soup } & \multirow{4}{*}{0.070} \\
\hline Only vegetables & $25.3 \pm 38.1$ & \\
\hline Vegetables + pulses & $13.9 \pm 31.1$ & \\
\hline Vegetables+ chorizo & $20.8 \pm 37.2$ & \\
\hline
\end{tabular}

* Statistical analysis was performed with a T-Student test: $P<0.05$

** Statistical analysis was performed with a One-way ANOVA: $\mathrm{P}<0.05$

${ }^{1}$ Composed menu: when the protein source mixed with the carbohydrate source or with vegetables

${ }^{2}$ Non composed menu: the protein source is supplied as a piece separate from other menu items

AC: Carbohydrates source

$\mathrm{CP}$ : Component of proteins

frequently less tasty. Dupertuis et al 2003 also found that patients under modified diets presented higher risk of malnutrition resulting from insufficient food intake and higher values of food waste (19).

In line with other authors, fish dishes presented high waste values that meat dishes (25).

Meals acceptability was lower for women. In opposite Dupertuis et al 2003 found that men wasted more food than women (19). However, differences found in food waste by men and women may be related to the bias associated with an unequal distribution between genders. In spite of no correlation has been found in our study between length of hospital stay and food waste, Dupertuis et al 2003 reported a decrease of waste with increase on hospital stay, attributable to a progressive 
adaptation to hospital meal service (19). Nevertheless, the length of hospital stay was much longer in our study, due to the specific characteristics of the institution.

Additionally, there was a great variability in the standard variation in food waste index (Table 5). This situation may reveal that inadequacies are associated with diets prescription. Possible explanations may be related to dietary prescription of "general diet" for non-dentition patients and with differences in the level of consciousness, misrepresentation and / or incorrect diet prescription collection by the hospital attendants, the lack of adjustments of dietary prescription to medical prescription, absence of standards during platting and lack of assistance by attendants to patient's incapable of self-eating. Additionally, medication may interfere with sensorial perception contributing to lack of appettite and consequently meals rejection (11).

\section{CONCLUSIONS}

Menus evaluated during the study period were not in accordance with the current dietary recommendations, namely regarding vegetables, fruits, sources of carbohydrates, fish and cooking techniques. High values of FWI were found. Low temperature of the carbohydrate source determined higher values of plate waste. Patients who wasted more soup also showed a lower acceptability of the main course. It will be necessary to increase supervision of the food service by nutritionists to ensure adequacy of menus in terms of nutritional and sensorial quality and adequacy to patient's needs.

Considering the nutritional impact of food waste, future research will be needed to access satisfaction and accomplishment of nutritional requirements.

\section{ACKNOWLEDGMENTS}

This work is financed by the FEDER Funds through the Operational Competitiveness Factors Program - COMPETE and by National Funds through FCT - Foundation for Science and Technology within the scope of the project UIDB/50006/2020.

\section{REFERENCES}

1. Kondrup J. Proper hospital nutrition as a human right. Clinical nutrition (Edinburgh, Scotland). 2004;23(2):135-7.

2. Garcia RWD. A dieta hospitalar na perspectiva dos sujeitos envolvidos em sua produção e em seu planejamento. Revista de Nutrição. 2006;19(2):129-44.

3. WHO. Obesity: preventint and managing the global epidemic. Report of a WHO Consulting. Geneva: World Health Organization; 2000.

4. Veiros M. B., Proença R. P. d. C. Avaliação Qaulitativa das Preparações do Cardápio em uma Unidade de Alimentação e Nutrição - Método AQPC. Nutrição em Pauta. 2003;11. 5. Bocardi SM, Volpato T, Gazzi L, da Roza AK, Barcelos ALV. Estado nutricional de pacientes atendidos em um centro de atenção psicossocial (CAPS). Unoesc \& Ciência-ACBS. 2015;6(1):73-80.

6. Kawasaki VM, Cyrillo DC, Machado FMS. Custo-efetividade da produção de refeições coletivas sob o aspecto higiênico-sanitário em sistemas cook-chill e tradicional. Revista de Nutrição. 2007;20:129-38.

7. Rodriguez Rejon Al, Ruiz Lopez MD, Malafarina V, Puerta A, Zuniga A, Artacho R. [Menus offered in long-term care homes: quality of meal service and nutritional analysis]. Nutr Hosp. 2017;34(3):584-92.

8. Grunert KG, Dean M, Raats MM, Nielsen NA, Lumbers M. A measure of satisfaction with food-related life. Appetite. 2007;49(2):486-93.

9. Proença RPdC. Novas tecnologias para a produção de refeições coletivas: recomendações de introdução para a realidade brasileira. Revista de Nutrição. 1999;12:43-53.

10. Teixeira S, Milet Z, Carvalho J, Biscontini TM. Administração Aplicada às Unidades de Alimentação e Nutrição. São Paulo: Ateneu; 2004.
11. Edwards JS, Nash AH. The nutritional implications of food wastage in hospital food service management. Nutrition \& Food Science. 1999.

12. Correia MI, Waitzberg DL. The impact of malnutrition on morbidity, mortality, length of hospital stay and costs evaluated through a multivariate model analysis. Clinical nutrition (Edinburgh, Scotland). 2003;22(3):235-9.

13. Veiros MB, Proença RPC, Kent-Smith I, Hering B, De Sousa AA. How to analyse and develop healthy menus in foodservice. Journal of Foodservice. 2006;17:159- 65. 14. Veiros MB, Campos G, Proença RPC, Rocha A, Kent-Smith I. Avaliação Qualitativa de Ementa - Método AQE. Alimentação Humana. 2007;13(3):62-78.

15. International standards for anthropometric assessment International Society for Advancement of Kinanthropometry; 2011.

16. Bessa V, Monteiro A, Rocha A. Proposta de Critérios para Avaliação qualitatva de Ementas. Alimentação Humana. 2009;15(3):73- 9.

17. Liz Martins M, Cunha LM, Rodrigues SS, Rocha A. Determination of plate waste in primary school lunches by weighing and visual estimation methods: a validation study. Waste management (New York, NY). 2014;34(8):1362-8.

18. Williams P, Walton K. Plate waste in hospitals and strategies for change. e-SPEN, the European e-Journal of Clinical Nutrition and Metabolism. 2011;6(6):e235-e41.

19. Dupertuis YM, Kossovsky MP, Kyle UG, Raguso CA, Genton L, Pichard C. Food intake in 1707 hospitalised patients: a prospective comprehensive hospital survey. Clinical Nutrition. 2003;22(2):115-23.

20. Dias-Ferreira C, Santos T, Oliveira V. Hospital food waste and environmental and economic indicators - A Portuguese case study. Waste Manage. 2015;46:146-54.

21. Lam IT, Keller HH, Duizer L, Stark K. Micronutrients on the Menu: Enhancing the Quality of Food in Long-term Care for Regular, Nontherapeutic Menus. Can J Diet Pract Res. 2015;76(2):86-92.

22. Simzari K, Vahabzadeh D, Saeidlou SN, Khoshbin S, Bektas Y. Food intake, plate waste and its association with malnutrition in hospitalized patients. Nutricion Hospitalaria. 2017;34(6):1376-81.

23. Thibault R, Chikhi M, Clerc A, Darmon P, Chopard P, Genton L, et al. Assessment of food intake in hospitalised patients: A 10-year comparative study of a prospective hospital survey. Clinical Nutrition. 2011;30(3):289-96.

24. Alshqaqeeq F, Twomey JM, Overcash MR. Food waste in hospitals. Int $\mathrm{J}$ Healthc Techno. 2018;17(2-3):186-96.

25. Henriques AS, Liz Martins M, Rocha A, editors. Evaluation and control of food waste in an elderly institution.2014. Uppsala, Sweden. : 28th EFFoST Conference.; 2014. 